\title{
Vertical and horizontal habitat preferences of post-nesting leatherback turtles in the South Pacific Ocean
}

\author{
George L. Shillinger ${ }^{1,9, *}$, Alan M. Swithenbank ${ }^{1}$, Helen Bailey ${ }^{2,3}$, Steven J. Bograd ${ }^{2}$, \\ Michael R. Castelton ${ }^{1}$, Bryan P. Wallace ${ }^{4,5}$, James R. Spotila ${ }^{6}$, Frank V. Paladino ${ }^{7}$, \\ Rotney Piedra ${ }^{8}$, Barbara A. Block ${ }^{1}$ \\ ${ }^{1}$ Hopkins Marine Station, Stanford University, 120 Oceanview Boulevard, Pacific Grove, California 93950, USA \\ ${ }^{2}$ NOAA/NMFS/SWFSC/Environmental Research Division, 1352 Lighthouse Avenue, Pacific Grove, California 93950, USA \\ ${ }^{3}$ Chesapeake Biological Laboratory, UMCES, Solomons, Maryland 20688, USA \\ ${ }^{4}$ Global Marine Division, Conservation International, 2011 Crystal Drive, Suite 500, Arlington, Virginia 22202, USA \\ ${ }^{5}$ Division of Marine Science and Conservation, Duke University Marine Laboratory, Beaufort, North Carolina 28516, USA \\ ${ }^{6}$ Department of Biology, Drexel University, Philadelphia, Pennsylvania 19104, USA \\ ${ }^{7}$ Department of Biology, Indiana-Purdue University, Fort Wayne, Indiana 46805, USA \\ ${ }^{8}$ Parque Nacional Marino Las Baulas, Ministerio de Ambiente y Energía y Telecomunicaciones, Apartado 10104-1000, \\ San José, Costa Rica \\ ${ }^{9}$ Present address: Center for Ocean Solutions, 99 Pacific Street, Suite 155A, Monterey, California 93940, USA
}

\begin{abstract}
Leatherback turtles are the largest and widest ranging turtle species, and spend much of their time in the offshore pelagic environment. However, the high seas have thus far received little management attention to protect their ecosystems and biodiversity. We tagged 46 female leatherback turtles with satellite transmitters at Playa Grande, Costa Rica from 2004 to 2007. In the present study, we analyzed the vertical and horizontal habitat preferences of these leatherback turtles in the South Pacific Ocean. The turtles exhibited short, shallow dives during their migration southward (mean depth: $45 \mathrm{~m}$; mean duration: $23.6 \mathrm{~min}$ ), followed by deeper, longer dives (mean depth: $56.7 \mathrm{~m}$; mean duration: $26.4 \mathrm{~min}$ ) in the South Pacific Gyre that probably indicated searching for prey. We integrated the horizontal movements with remotely sensed oceanographic data to determine the turtles' response to the environment, and applied this information to recommendations for conservation in the pelagic environment. A generalized additive mixed model applied to the daily turtle travel rates confirmed that slower travel rates occurred at cooler sea surface temperatures, higher chlorophyll a concentration and stronger vertical Ekman upwelling, all of which are considered favorable foraging conditions. The southern terminus $\left(35\right.$ to $\left.37^{\circ} \mathrm{S}\right)$ of the leatherback tracks was also in an area of increased mesoscale activity that might act as a physical mechanism to aggregate their prey, gelatinous zooplankton. However, this could also act as a thermal limit to their distribution. This characterization of leatherback habitat use could aid the development of management efforts within the South Pacific Ocean to reduce mortality of leatherback turtles from fisheries interactions.
\end{abstract}

KEY WORDS: Leatherback turtle · Post-nesting migration · Generalized additive models · Sea surface temperature $\cdot$ Surface chlorophyll concentration $\cdot$ Satellite tracking $\cdot$ Remote sensing

\section{INTRODUCTION}

The recent precipitous decline of leatherback turtles Dermochelys coriacea in the Pacific is well established and has been attributed to various human-related impacts, including habitat loss, poaching, and fisheries interactions. Long-term monitoring studies of female turtle nesting assemblages at beaches in Mexico (Sarti Martínez et al. 2007) and Costa Rica (Spotila et al. 2000) have demonstrated that the most marked popu- 
lation declines have occurred within the eastern Pacific (Eckert \& Sarti 1997, Spotila et al. 2000). Conservation efforts, including reduction or elimination of turtle poaching and egg collection, relocation of at-risk (i.e. from tidal inundation, poaching) nests, and increased local community participation in turtle conservation have contributed to turtle protection and recruitment at nesting beaches (Santidrián Tomillo et al. 2007). Unfortunately, nesting beach conservation efforts alone have not been sufficient to reduce mortality (overall annual rate estimated at $\sim 22 \%$ for the nesting population at Playa Grande, Costa Rica; Santidrián Tomillo et al. 2008) from interactions with artisanal and commercial fisheries (Eckert \& Sarti 1997, Lewison et al. 2004, Alfaro-Shigueto et al. 2007, Donoso \& Dutton 2010), which continues to present an ongoing threat to the long-term survival of eastern Pacific leatherbacks. Thus, a clear need exists to develop integrated management strategies that address turtle conservation needs during multiple life-history stages, particularly within oceanic habitats where turtles appear to be at highest risk.

Recent advances in biologging technologies have facilitated the development of long-term satellitetracking data sets for many marine species (Block et al. 2002, Hart \& Hyrenbach 2009). These new technologies, in combination with remotely sensed oceanographic data, have enabled researchers to identify high-use habitats, migration patterns, and environmental influences on marine turtle behavior (e.g. Hays et al. 2006, Shillinger et al. 2008). Satellite tag deployments on nesting females in Costa Rica (Morreale et al. 1996, Shillinger et al. 2008) and Mexico (Eckert \& Sarti 1997) have revealed that leatherbacks engage in extensive southward migrations to distant high-seas foraging habitats within the South Pacific Gyre. These post-nesting migrations are characterized by an initial departure phase during which females engage in rapid directed movements through the highly energetic equatorial zonal current system (Shillinger et al. 2008), followed by a dispersal phase into the oligotrophic South Pacific Gyre region. To date, the high seas have received little management attention to protect their ecosystems or biodiversity (Ardron et al. 2008, Game et al. 2009), in spite of the recognized importance of these regions as migration, foraging, and breeding habitats for many pelagic species (Hyrenbach et al. 2000, Block et al. 2002, Olson \& Galván-Magaña 2002).

There has been great interest in the application of marine spatial planning to reduce anthropogenic impacts (Halpern et al. 2008) and to promote sustainable use of marine resources (Douvere et al. 2007). These approaches have been applied predominantly to coastal environments, but they could also be utilized on the high seas to develop marine protected areas (Hyrenbach et al. 2000) and determine ecologically appropriate fishing areas that will minimize bycatch of unwanted species in multi-national marine regions (Ardron et al. 2008). Spatio-temporal characterization of critical habitat for protected species is an essential first step for identifying conservation priority areas and proposing marine protected area boundaries (Cañadas et al. 2005, Bailey \& Thompson 2009).

Although the broad-scale horizontal movements of leatherback turtles within the eastern Pacific have been described (Morreale et al. 1996, Reina et al. 2005, Southwood et al. 2005, Shillinger et al. 2008), little is known about the fine-scale use, horizontal or vertical, of post-nesting habitats. There has also been no quantification of eastern Pacific leatherback environmental habitat preferences (Shillinger et al. 2008, 2010, Saba et al. 2008). In the present study, we analyzed for the first time the vertical dive patterns of female leatherback turtles during their post-nesting movements in the South Pacific Ocean. This was compared to changes in the horizontal movements to confirm where shifts in behavior occurred. We then developed a habitat use model using daily turtle speeds as a proxy for habitat preference and combined this with satellitederived environmental data. We finally provide recommendations for conservation measures aimed at mitigating human impacts on leatherbacks and suggest the development of a high-seas pelagic protected area in the southeast Pacific Ocean.

\section{MATERIALS AND METHODS}

Tagging and data processing. We instrumented 36 female leatherback turtles with Sea Mammal Research Unit (SMRU) satellite relay data logger (SRDL) tags during 2004 ( $\mathrm{n}=17), 2005$ ( $\mathrm{n}=8)$, and 2007 ( $\mathrm{n}=11)$. The SRDL tags were programmed to collect and transmit position, temperature, dive data, and tag diagnostic information. Ten additional turtles were tagged during 2004 with Wildlife Computer Smart Position Only (SPOT) tags, which were programmed to provide position data. We mounted the satellite transmitters on the turtles using a harness technique during oviposition (Eckert 2002). This was the standard technique at the time (Shillinger et al. 2010), although direct attachment is now the more popular method (Doyle et al. 2008, Fossette et al. 2008, Byrne et al. 2009). Data from the tags were transmitted via the ARGOS satellite system (Shillinger et al. 2008).

Dive data. A pressure sensor on the SRDL tags provided dive data (to accuracy of $0.33 \mathrm{~m}$ ). Dive initiation and termination were determined by the tag's conductivity sensor. Profiles were recorded for all dives 
deeper than $10 \mathrm{~m}$. Bespoke software onboard the tag was utilized to examine dive profiles and to identify 5 significant inflection points within the dive (Fedak et al. 2002). Information about the geoposition of dive profiles, dive start and end times, and dive profile inflection points were provided, along with maximum dive depth attained on individual dives, summary dive data (e.g. proportion of time spent diving $<10 \mathrm{~m}$, mean dive depths and durations for dives $>10 \mathrm{~m}$ ) in $6 \mathrm{~h}$ bins, and tag diagnostic information (Fedak et al. 2002, Hays et al. 2004). We used the tag summary and diagnostic information to filter inaccurate dive profiles from the dive tables within SMRU-developed database queries. We used the MATLAB 'Air_Sea' package (version 2.0, August 5, 1999, http://woodshole.er.usgs. gov/) to partition day and night vertical behavior. The 'Air Sea' code calculates solar altitude and computes the time of sunrise and sunset to the nearest minute in GMT for a calendar day at each geoposition. A 1-way ANOVA and Tukey's post hoc tests were used to test for differences in dive behavior among years, and between day and night using the $\mathrm{R}$ software package ( $\mathrm{R}$ Development Core Team 2008).

We extracted water temperature measurements from the temperature-at-depth data transmitted by the SRDL tags. Surface was considered to be the first depth bin (mean \pm SD: $5.1 \pm 0.7 \mathrm{~m}$ ). We discarded 5975 raw casts from a total of 9785 records because the first depth was missing, had a negative value, had spurious position values, or the cast did not meet the requirements for applying a Loess filter to $1 \mathrm{~m}$ depth bins (e.g. single-step depth $[z]$ difference $>350 \mathrm{~m}$, single-step temperature $[T]$ difference $>30^{\circ} \mathrm{C}, 2$ or more $T$ or $Z$ difference values $>0$ ). The $1 \mathrm{~m}$ interval temperatureat-depth data were obtained by Loess filtering the 12 temperature-at-depth points provided by the tag. These data were used to produce log frequency temperature-depth plots. For each $1 \mathrm{~m}$ depth interval, the temperature at peak utilization was identified and fit with a third-order polynomial.

Track interpolation and behavioral mode interpretation. Final position estimates at daily intervals were calculated using a switching state-space model (SSSM), which was applied to all of the raw Argos positions. This model incorporated the behavioral process (transition equation) and error for each of the location classes (measurement equation) to improve the position estimates (Jonsen et al. 2007). Six-hourly SSSM position estimates were also generated to align with SMRU summary dive data (Bailey et al. 2008, Shillinger et al. 2008). Application of a SSSM provided the capacity to discern between 2 behavioral modes based on a first-difference correlated random walk. The location of the switch between these 2 behavioral modes was used to objectively define the transition from internesting ('Mode 2') to the post-nesting migration ('Mode 1') for this tracking data set (Bailey et al. 2008). The $8.27^{\circ} \mathrm{S}$ mean transition latitude separating the migration phase from the foraging phase was based upon the mean location of a behavioral shift back from Mode 1 to Mode 2 identified by the SSSM for all tracks (Bailey et al. 2008). Our analysis also indicated a clear modal switch at this latitude from high mean daily travel rates $\left(>25 \mathrm{~km} \mathrm{~d}^{-1}\right)$ to a phase of persistently low mean daily travel rates $\left(<25 \mathrm{~km} \mathrm{~d}^{-1}\right)$ (Fig. 1a) (Shillinger et al. 2008).

Satellite-derived environmental data. Remotely sensed environmental data were obtained from http:// coastwatch.pfel.noaa.gov. These data sets included time series of science-quality products for sea surface temperature (SST), surface chlorophyll a (chl a) concentration, sea surface height (SSH), SSH variability (root mean square, SSHRMS), vertical current due to Ekman pumping (Ekman), and SST frontal probability index (FPI). We calculated a mean value for each oceanographic variable within a box $\left(0.2^{\circ}\right.$ longitude $\times$ $0.2^{\circ}$ latitude $\times(5$ to $10 \mathrm{~d})$ ) centered at the time and position of each daily SSSM-interpolated turtle position. These values were utilized to describe the environmental conditions surrounding each turtle location.

SST data were obtained from http://coastwatch. pfeg.noaa.gov/coastwatch/CWBrowserWW360.jsp. These SST data were blended at spatial scale of $0.1^{\circ}$ in 5 d composites from multiple sources, including Advanced Very High Resolution Radiometer (AVHRR) data from NOAA Polar Spacecraft (Polar Operational Environmental Satellites-POES), Moderate Resolution Imaging Spectroradiometer (MODIS) from NASA AQUA/ TERRA Spacecraft (EOS AM-1/PM-1) and the Imager sensor onboard the NOAA Geostationary Spacecraft (GOES), and Advanced Microwave Scanning Radiometer (AMSR-E) data. The chl a data were obtained from $8 \mathrm{~d}$ composites provided by the MODIS $\left(0.05^{\circ} \times 0.05^{\circ}\right)$ sensor on the NASA AQUA/TERRA Spacecraft. The SSH data (gridded SSH computed in relation to a 7 yr mean) were obtained from the Centre National d'Etudes Spatiales (CNES) Aviso/Altimetry project (www.aviso.oceanobs.com; Ducet et al. 2000). Data were collected from the Geostat Follow-On (GFO) and Envistat sensors $\left(0.25^{\circ} \times 0.25^{\circ}\right)$ onboard the Jason-1 spacecraft. The altimeter products were produced by Ssalto/Duacs and distributed by Aviso, with support from CNES (www.aviso.oceanobs.com/duacs/). The FPI was calculated for $10 \mathrm{~d}$ intervals from application of gradient threshold tests and frontal feature tracking algorithms to daily SST GOES Imager data at a resolution of $0.5^{\circ} \times 0.5^{\circ}$. Ekman pumping (vertical Ekman upwelling) data describing the vertical movement of water in relation to horizontal water displacement at the sea surface were calculated from algo- 

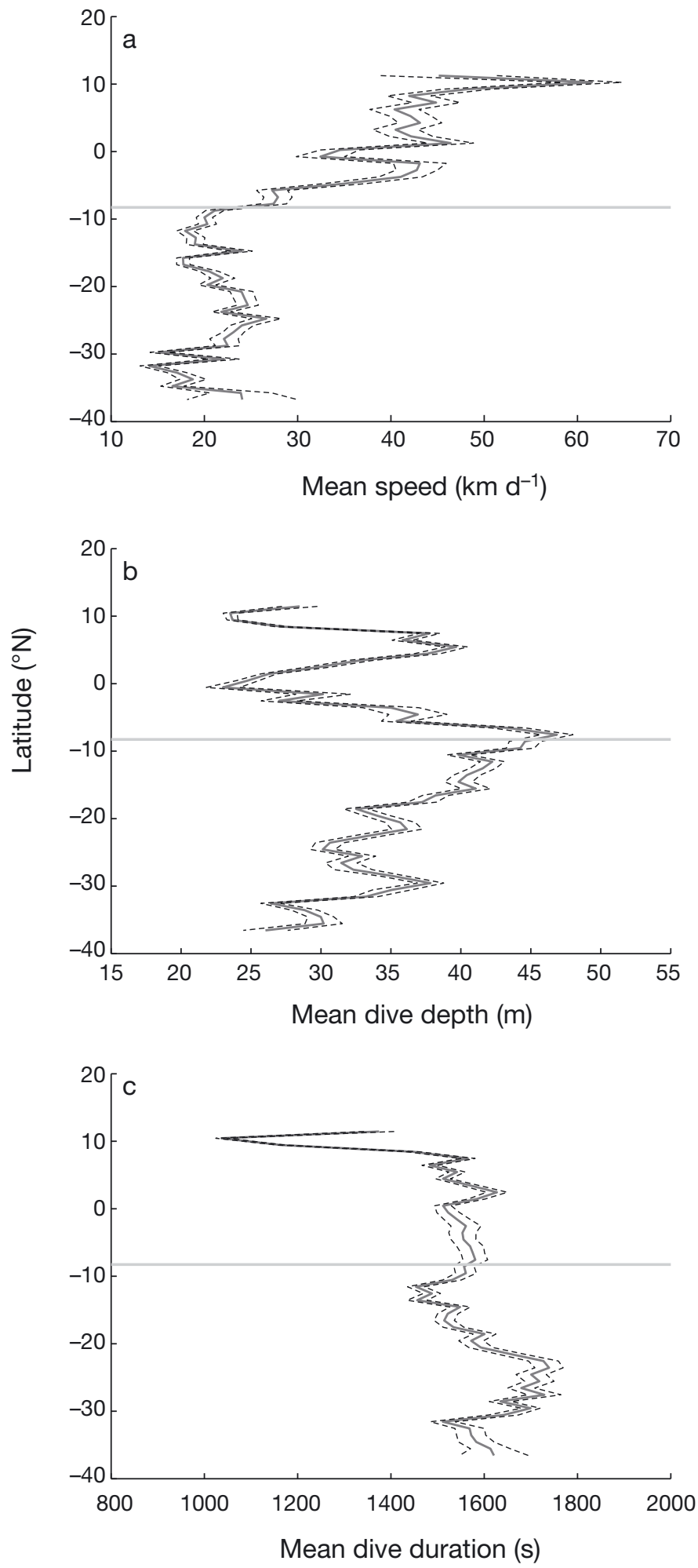

Fig. 1. Dermochelys coriacea. (a) Speed, (b) dive depth, and (c) dive duration versus latitude $\left(1^{\circ}\right.$ bins) for all post-nesting leatherback turtles tagged at Playa Grande, Costa Rica; data are zonal mean (mid-gray line) and standard error of the mean (black dashed lines). The mean latitude of the switching statespace model mode shift from migration to foragingmode is shown (horizontal light-gray line) rithms integrating horizontal current movements from the base of the Ekman layer to the surface. Ocean wind velocity data used in these calculations were obtained from the SeaWinds sensor on the QuikSCAT satellite and further processed by NOAA Coastwatch (http://coastwatch.noaa.gov/) into wind stress and wind stress curl components. Ekman upwelling data were extracted for each position estimate from $8 \mathrm{~d}$ composites of derived Ekman upwelling data product, mapped to a $0.25^{\circ} \times 0.25^{\circ}$ grid.

Environmental information associated with the turtle locations were visualized and qualitatively assessed through the use of ArcGIS (version 9.3) and ArcView (version 3.2) software. We created histograms to examine the relative frequency occurrence of the satellite-derived environmental variables during the migration and foraging phases of the postnesting tracking period.

Statistical analyses. We applied a generalized additive model to examine the influence of environmental variables (SST, chl a, SSHRMS, FPI, Ekman upwelling) on daily turtle travel rate during their post-nesting movements. Turtle travel rate was chosen as the response variable based on the premise that animals would reduce their transit rates within areas of increased foraging success (Fauchald \& Tveraa 2003, Kuhn et al. 2009). Data exploration of the variables indicated that a logarithmic transformation was required for chl $a$ and SSHRMS, and an arcsine transformation for FPI (limited between 0 and 1). We then tested for collinearity between the explanatory environmental variables by calculating the pairwise correlations and the variance inflation factor. All of the pairwise correlations were $\leq 0.4$, and the variance inflation values were all $<3$, indicating that there was no significant collinearity between our explanatory variables (Zuur et al. 2009). Examination of the relationships between the response and explanatory variables indicated that the majority were non-linear. We therefore applied a generalized additive mixed model (GAMM), which enabled us to fit smoothed non-linear curves through the explanatory variables. The individual tracks were included as a random effect to account for the correlation in travel rate within each turtle track. The error distribution was Gaussian with an identity link function. The smoother terms were derived using penalized regression splines with a shrinkage term, so that for large-enough smoothing, a smoother could have 0 degrees of freedom and be effectively removed from the model (Wood 2006). The model was applied using the R software package (R Development Core Team 2008) and contributed package mgcv (Wood 2006). 


\section{RESULTS}

\section{Track durations}

A total of $13038 \mathrm{~d}$ of movements were recorded (2004: 8189 d; 2005: 2157 d; 2007: 2692 d) throughout the entire leatherback tracking data set. The total tracking period per turtle ranged from 57 to $563 \mathrm{~d}$ (mean \pm SD: $244.7 \pm 157.7 \mathrm{~d}$ ). Post-nesting track durations for turtles that engaged in directed offshore movements $(\mathrm{n}=45)$ had a mean duration of $217.8 \pm$ $169.6 \mathrm{~d}$ (range: 40 to $514 \mathrm{~d}$ ). The longest total tracking duration in the entire post-nesting data set was achieved by the only turtle (the turtle with platform transmitter terminal [PTT] tag 56280 in 2005) with a coastal migration strategy (Shillinger et al. 2008, 2010). This turtle spent the entire tracking duration transiting between foraging patches along the coast of Costa Rica and Panama, and was considered separately from the rest of the tracking data set in all further analyses. The remaining 45 turtles migrated in a predominantly southwesterly direction from the nesting beach towards distant offshore habitats (Shillinger et al. 2008). There were 31 tracks that continued beyond $8.27^{\circ} \mathrm{S}$ into putative foraging grounds, all of which moved south into the South Pacific Gyre.

\section{Vertical movements}

A total of 42234 post-nesting dive depth observations were recorded for the 35 SMRU SRDL tagged turtles after filtering. The total number of dives observed per turtle ranged from 118 to 3534 (mean \pm SD: $1173 \pm$ 850 dives), with a mean depth of $49.2 \pm 10.1 \mathrm{~m}$, and mean maximum depth of $668.4 \pm 172.8 \mathrm{~m}$ (Table 1). Mean dive depths varied significantly among years (ANOVA: $F_{2,32}=4.26, \mathrm{p}=0.02$ ), and based on Tukey's post hoc tests, were significantly deeper in 2004 (mean: $53.7 \pm 8.6 \mathrm{~m}$ ) than in 2005 (mean: $42.8 \pm 12.7 \mathrm{~m}$ ). The mean dive depth during the foraging phase (56.7 \pm $14.3 \mathrm{~m})$ was significantly deeper than during the migration phase $(45.0 \pm 9.1 \mathrm{~m})$ (ANOVA: $F_{1,42229}=$ 231.41, p < 0.01) (Fig. 1b).

There was no significant difference in mean dive durations between years (Table 1 ; ANOVA: $F_{2,32}=$ $2.22, \mathrm{p}=0.13)$. The mean dive duration during the foraging phase for all years was $26.4 \pm 5.3 \mathrm{~min}$ and was significantly longer than during migration (23.6 \pm $4.1 \mathrm{~min}$ ) (ANOVA: $F_{1,42229}=579.24, \mathrm{p}<0.01$ ) (Fig. 1c). The longest recorded dive duration of $89.1 \mathrm{~min}$ to a depth of $882 \mathrm{~m}$ (turtle PTT 41701) occurred on May 16, $2004\left(13.2^{\circ} \mathrm{S}, 105.63^{\circ} \mathrm{W}\right)$.

Turtle mean dive depths were significantly greater during the day than at night $(\mathrm{n}=17633$; day: $64.7 \pm 17.2 \mathrm{~m}$; night: $38.4 \pm 7.2 \mathrm{~m}$ ) (ANOVA: $F_{1,42229}=37561.28, \mathrm{p}<$ $0.01)$. In contrast, mean dive durations were significantly longer at night $(25.3 \pm 4.5 \mathrm{~min})$ than in the day $(24.6 \pm 4.1$ min) (ANOVA: $F_{1,42229}=39.94, \mathrm{p}<0.01$ ). There were a total of 12 dives $>800 \mathrm{~m}(\sim 0.00003 \%$ of total dive records) and 57 dives with durations $>4000 \mathrm{~s}$ (66.7 $\mathrm{min}$; $<0.0015 \%$ of total). The majority of very deep dives occurred during the migration phase (10 of 12 dives) and during daytime (11 of 12 dives).

Tag-derived temperature at depth indicated that turtles occupied a wide vertical thermal range (3.6 to $34.4^{\circ} \mathrm{C}$ ) during the post-nesting tracking duration. Turtles experienced the lowest temperatures during deeper dives, particularly those below 200 m (Fig. 2). Turtles occupied a relatively consistent, narrow thermal range $\left(5\right.$ to $\left.8^{\circ} \mathrm{C}\right)$ around their maximum dive depths.

\section{Horizontal movements}

The total region occupied by turtles during the postnesting period spanned from $11.75^{\circ} \mathrm{N}$ to $37.61^{\circ} \mathrm{S}$ and from 78.54 to $133.31^{\circ} \mathrm{W}$ (Fig. 3). The mean maximum total distance that post-nesting turtles traveled from their tag deployment location was $3355 \pm 1862 \mathrm{~km}$ (range: 355 to $7286 \mathrm{~km}$ ), with mean individual turtle daily travel rates ranging from 6.7 to $25.4 \mathrm{~km} \mathrm{~d}^{-1}$, and a grand mean for all turtles of $15.3 \pm 4.4 \mathrm{~km} \mathrm{~d}^{-1}$.

Tag-derived SST experienced by the turtles averaged $26.2 \pm 1.4^{\circ} \mathrm{C}$ (range: 13.5 to $34.4^{\circ} \mathrm{C}$ ). This was highest (mean: $26.8 \pm 1.2^{\circ} \mathrm{C}$ ) during the migration phase and lowest (mean: $19.4 \pm 3.9^{\circ} \mathrm{C}$ ) during the southern foraging phase.

\section{Surface environmental characteristics}

The migration corridor was characterized by high SST, high chl $a$, and broad regions of strong mesoscale activity, as indicated by elevated values of SSHRMS and FPI (Fig. 4). In contrast, the foraging zone was characterized by lower SST, weak productivity, and generally low SSHRMS and FPI until about 30 to $37^{\circ} \mathrm{S}$, where the values increased again. These environmental differences between behavioral phases were evident in the frequency histograms of SST and chl a within the 2 regions (Fig. 5).

Application of a GAMM revealed that all of the environmental parameters examined had a significant relationship with turtle travel rate (Table 2). Higher turtle travel rates were generally associated with warmer SSTs and mid-range chl a $\left(\sim 0.55 \mathrm{mg} \mathrm{m}^{-3}\right)$, as well as enhanced mesoscale activity (indicated by higher SSHRMS and FPI) (Fig. 6). Lower turtle travel rates were 
Table 1. Dermochelys coriacea. Leatherback turtle post-nesting vertical movements. na: not available; PTT: platform transmitter terminal

\begin{tabular}{|c|c|c|c|c|c|c|c|c|}
\hline \multirow{2}{*}{$\begin{array}{l}\text { PTT } \\
\text { ID }\end{array}$} & \multirow{2}{*}{$\begin{array}{l}\text { Total no. } \\
\text { of dives }\end{array}$} & \multicolumn{3}{|c|}{ Dive depth (m) } & \multicolumn{2}{|c|}{ — Dive duration (min) } & \multirow{2}{*}{$\overline{\mathrm{SD}}$} & \multirow{2}{*}{$\begin{array}{l}\text { Dive freq. } \\
\text { (\% time spent } \\
\text { diving) }\end{array}$} \\
\hline & & Max. & Mean & SD & Max. & Mean & & \\
\hline \multicolumn{9}{|l|}{2004} \\
\hline 37595 & 1503 & 690 & 70.64 & 58.01 & 68.50 & 28.66 & 11.32 & 67.21 \\
\hline 37596 & 227 & 690 & 42.8 & 48.8 & 57.83 & 26.88 & 8.01 & 61.77 \\
\hline 41687 & na & na & na & na & na & na & na & na \\
\hline 41688 & na & na & na & na & na & na & na & na \\
\hline 41689 & na & na & na & na & na & na & na & na \\
\hline 41690 & na & na & na & na & na & na & na & na \\
\hline 41691 & na & na & na & na & na & na & na & na \\
\hline 41692 & na & na & na & na & na & na & na & na \\
\hline 41693 & na & na & na & na & na & na & na & na \\
\hline 41694 & na & na & na & na & na & na & na & na \\
\hline 41695 & na & na & na & na & na & na & na & na \\
\hline 41696 & na & na & na & na & na & na & na & na \\
\hline 41697 & 789 & 658 & 54.98 & 52.07 & 69.83 & 17.12 & 7.48 & 52.15 \\
\hline 41698 & 1270 & 818 & 54.47 & 52.26 & 65.83 & 27.10 & 8.61 & 66.96 \\
\hline 41699 & 671 & 882 & 58.58 & 69.58 & 68.50 & 23.60 & 8.71 & 67.79 \\
\hline 41700 & 553 & 690 & 44.69 & 47.66 & 57.83 & 31.24 & 11.96 & 72.96 \\
\hline 41701 & 600 & 882 & 57.84 & 73.09 & 69.83 & 34.52 & 12.95 & 71.38 \\
\hline 41702 & 1238 & 818 & 67.2 & 51.42 & 78.50 & 26.21 & 10.59 & 68.83 \\
\hline 41703 & 702 & 690 & 52.49 & 55.26 & 63.17 & 24.47 & 9.34 & 75.66 \\
\hline 41704 & 1738 & 690 & 59.35 & 49.02 & 63.17 & 23.77 & 7.99 & 67.67 \\
\hline 41705 & 1629 & 506 & 60.39 & 40.38 & 78.50 & 24.16 & 10.36 & 66.2 \\
\hline 41706 & 660 & 722 & 53.38 & 65.18 & 44.50 & 22.46 & 6.85 & 74.16 \\
\hline 41707 & 1499 & 658 & 40.48 & 36.6 & 64.50 & 22.37 & 11.78 & 66.06 \\
\hline 41708 & 2076 & 818 & 58.7 & 49.37 & 65.83 & 24.19 & 10.13 & 73.03 \\
\hline 41709 & 1048 & 378 & 47.47 & 37.7 & 78.50 & 18.50 & 7.97 & 65.75 \\
\hline 41710 & 2025 & 818 & 46 & 52.31 & 67.17 & 26.60 & 14.01 & 69.65 \\
\hline 41711 & 118 & 346 & 43.81 & 51.21 & 30.83 & 18.05 & 4.94 & 51.15 \\
\hline Mean \pm SD & $1079.2 \pm 600.4$ & $691.4 \pm 156.5$ & $53.7 \pm 8.6$ & 52.3 & $64.3 \pm 12.0$ & $24.7 \pm 4.5$ & 9.6 & $67.0 \pm 6.8$ \\
\hline \multicolumn{9}{|l|}{2005} \\
\hline 56268 & 200 & 658 & 46.43 & 66.7 & 48.50 & 20.53 & 6.46 & 71.83 \\
\hline 56272 & 350 & 754 & 38.43 & 53.75 & 75.83 & 22.37 & 6.62 & 59.88 \\
\hline 56274 & 305 & 394 & 49.25 & 40.01 & 52.50 & 27.83 & 7.86 & 78.6 \\
\hline 56276 & 586 & 506 & 28.62 & 34.11 & 48.50 & 15.85 & 6.62 & 71.05 \\
\hline 56279 & 2884 & 594 & 66.72 & 59.12 & 69.83 & 29.87 & 11.47 & 79.66 \\
\hline $56280^{\mathrm{a}}$ & 2368 & 282 & 52.39 & 49.43 & 78.50 & 29.12 & 13.48 & 85.01 \\
\hline 56282 & 352 & 298 & 36.17 & 32.42 & 35.17 & 20.53 & 7.32 & 61.9 \\
\hline 56283 & 685 & 658 & 34.09 & 41.6 & 45.83 & 20.86 & 6.44 & 73.48 \\
\hline Mean \pm SD & $966.3 \pm 1045.2$ & $518.0 \pm 177.4$ & $44.0 \pm 12.2$ & 47.1 & $56.8 \pm 15.8$ & $23.4 \pm 5.0$ & 8.3 & $72.7 \pm 8.6$ \\
\hline $\begin{array}{l}\text { Mean } \pm \text { SD } \\
\text { (excl. PTT 56280) }\end{array}$ & $766.0 \pm 948.9$ & $551.7 \pm 161.6$ & $42.8 \pm 12.7$ & 46.8 & $53.7 \pm 14.2$ & $22.5 \pm 4.8$ & 7.5 & $70.9 \pm 7.6$ \\
\hline \multicolumn{9}{|l|}{2007} \\
\hline 72474 & 2727 & 882 & 46.39 & 48.13 & 75.83 & 25.11 & 9.03 & 67.25 \\
\hline 72475 & 3534 & 850 & 47.02 & 42.31 & 72.50 & 27.47 & 11.10 & 74.45 \\
\hline 72476 & 1340 & 626 & 48.61 & 56.28 & 53.83 & 23.74 & 7.17 & 64.05 \\
\hline 72477 & 473 & 626 & 42.47 & 44.59 & 52.50 & 29.98 & 9.49 & 72.18 \\
\hline 72478 & 484 & 562 & 39.22 & 36.64 & 51.17 & 20.78 & 7.40 & 69.96 \\
\hline 72479 & 704 & 530 & 37.13 & 33.05 & 56.50 & 26.91 & 7.07 & 74.2 \\
\hline 72480 & 1088 & 914 & 47.94 & 64.87 & 83.83 & 32.04 & 11.30 & 69.94 \\
\hline 72481 & 497 & 754 & 37.75 & 51.91 & 55.17 & 28.83 & 9.07 & 64.8 \\
\hline 72482 & 1769 & 754 & 38.27 & 44.57 & 69.83 & 28.55 & 12.52 & 74.23 \\
\hline 72483 & 2338 & 850 & 62.5 & 64.27 & 57.83 & 26.00 & 7.95 & 61.64 \\
\hline 72485 & 1204 & 818 & 57.35 & 63.78 & 57.83 & 25.70 & 7.32 & 72.12 \\
\hline Mean \pm SD & $1468.9 \pm 1020.6$ & $742.4 \pm 135.2$ & $45.9 \pm 8.2$ & 50.0 & $62.4 \pm 11.1$ & $26.8 \pm 3.1$ & 9.0 & $69.5 \pm 4.5$ \\
\hline Total & 42234 & & & & & & & \\
\hline Grand mean $\pm \mathrm{SD}$ & $1173.2 \pm 850.0$ & $668.4 \pm 172.8$ & $49.2 \pm 10.1$ & 50.5 & $62.1 \pm 12.6$ & $25.1 \pm 4.3$ & 9.1 & $69.0 \pm 6.8$ \\
\hline $\begin{array}{l}\text { Grand mean } \pm \text { SD } \\
\text { (excl. PTT 56280) }\end{array}$ & $1139.0 \pm 837.0$ & $679.5 \pm 161.9$ & $49.1 \pm 10.3$ & & $61.6 \pm 12.5$ & $24.9 \pm 4.3$ & & $68.6 \pm 6.4$ \\
\hline
\end{tabular}



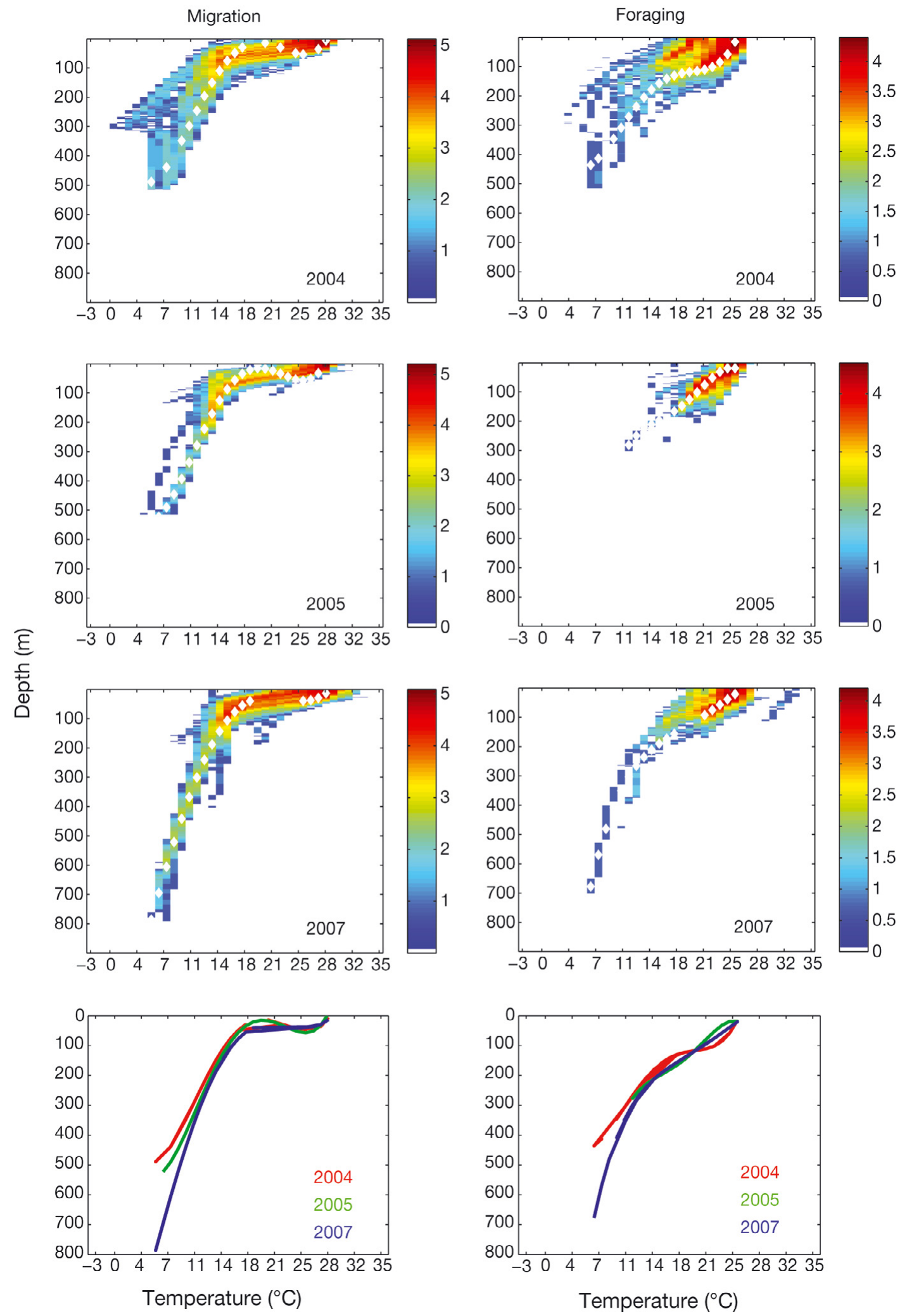

Fig. 2. Dermochelys coriacea. Turtle occupancy within a temperature and depth space during migration (left panels) and foraging (right panels). Log of frequency of occupancy within a temperature and depth $(T-z)$ space defined as $T=1^{\circ} \mathrm{C}$ by $z=1 \mathrm{~m}$ boxes for 2004, 2005, and 2007. The white diamonds refer to a third-order fit through the peak temperature utilization points within each $1 \mathrm{~m}$ depth interval and are shown for each year in the bottom panels 


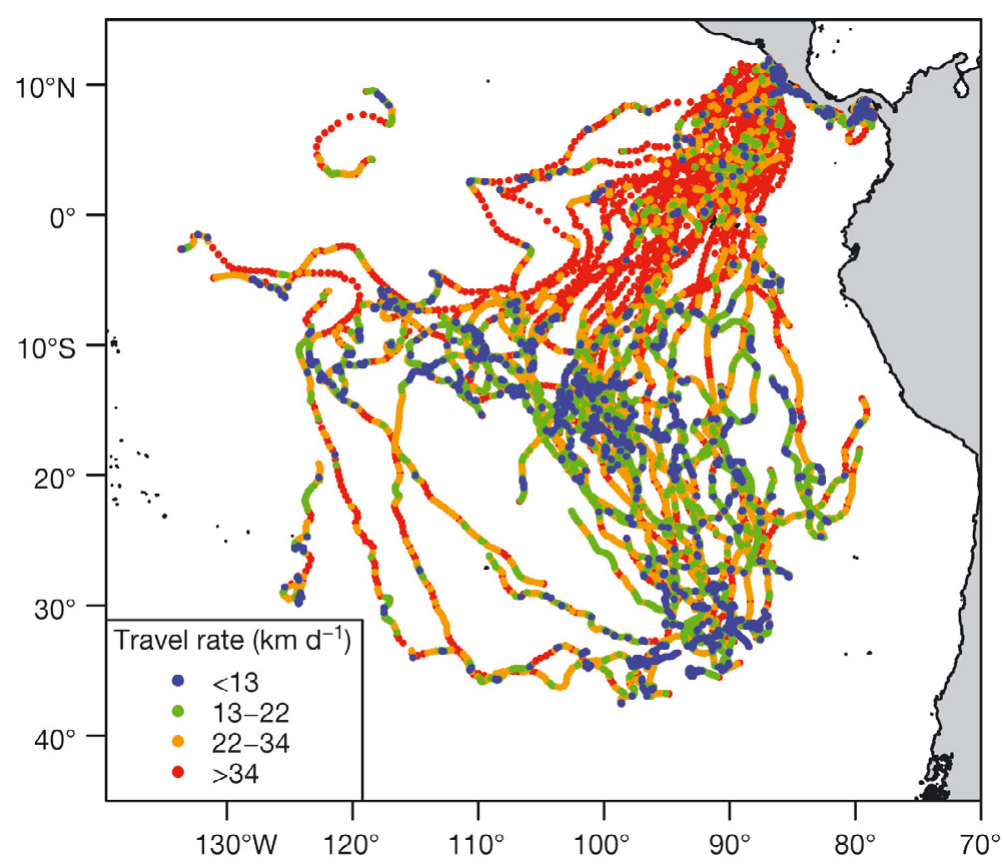

Fig. 3. Dermochelys coriacea. Switching state-space model-derived daily positions for eastern Pacific leatherback turtles tagged at Playa Grande, Costa Rica $(\mathrm{n}=46)$, color-coded by daily travel rate

ously been identified based on their horizontal movements (Bailey et al. 2008), suggesting that turtles were probably searching for food in this region. Integrated management of this high-seas area should be provided for the rapidly declining Pacific leatherback turtles, and could also benefit other species that use this area, such as green turtles Chelonia mydas (Seminoff et al. 2008), olive ridley turtles Lepidochelys olivacea (Plotkin et al. 1995), sperm whales Physeter macrocephalus (Whitehead et al. 2008), humpback whales Megaptera novaeangliae (Rasmussen et al. 2007), and several dolphin species (Redfern et al. 2008).

Although direct estimates of prey abundance (gelatinous zooplankton) in the South Pacific Gyre are unavailable, we found a significant association between a proxy of foraging behavior (i.e. turtle travel rates) and remotely sensed environmental variables favorable to leatherback foraging. Specifically, slower travel rates (indicating foraging behavior) occurred where there was lower SST, higher chl a concentration, and stronger vertical Ek-

generally associated with cooler SSTs and stronger vertical Ekman upwelling, environmental characteristics that suggest higher primary productivity and therefore higher prey levels. However, lower travel rates were also associated with both very low (southern) and very high chl a concentrations (Figs. 4 \& 6). However, all of these relationships were non-linear, revealing a dynamic and complex association between turtle foraging behavior and oceanography.

\section{DISCUSSION}

\section{Leatherback turtle habitat preference}

Understanding the movements and behavior of highly migratory species is fundamental for marine conservation efforts. Characterizing these species' movements, both horizontally and vertically, enables managers to anticipate where and when potential interactions might occur between these animals and anthropogenic activities in the same region (Howell et al. 2008, McClellan et al. 2009). The present study has highlighted the importance of the South Pacific Gyre for post-nesting eastern Pacific leatherback turtles. Significantly deeper and longer dives within the southern parts of their tracks (south of $8.27^{\circ} \mathrm{S}$ ) confirmed that a change in behavior had occurred that had previman upwelling (Fig. 6). This suggested that the turtles were foraging at higher latitudes, where there were upwellings of cooler, deeper water that resulted in increased productivity, indicated by the higher chl a concentration, and hence increased prey abundance. Although leatherback foraging behavior has been associated with mesoscale features (Doyle et al. 2008, Lambardi et al. 2008), slower travel rates were not associated with indicators of these features (SSHRMS and FPI) in our GAMM analysis. The strong equatorial currents (and high mesoscale activity) through which leatherbacks rapidly migrate (Bailey et al. 2008, Shillinger et al. 2008) might have masked any finer-scale or subtler associations further south. These strong zonal currents may have made it more difficult for turtles to remain with equatorial high chl a areas during the migration phase. However, several turtles within different tracking years engaged in zonal movements along the temperature frontal region (South Pacific Subtropical Convergence; Saba et al. 2008) in the southernmost part of their range, or changed direction at this point $\left(\sim 37^{\circ} \mathrm{S}\right)$ and returned to mid-latitude habitats within the center of the South Pacific Gyre. The southern edges of the Gyre are characterized by increased mesocale activity (relatively high FPI and SSHRMS; Fig. 4) and higher net primary production (Saba et al. 2008). Eastern Pacific leatherback turtles may 

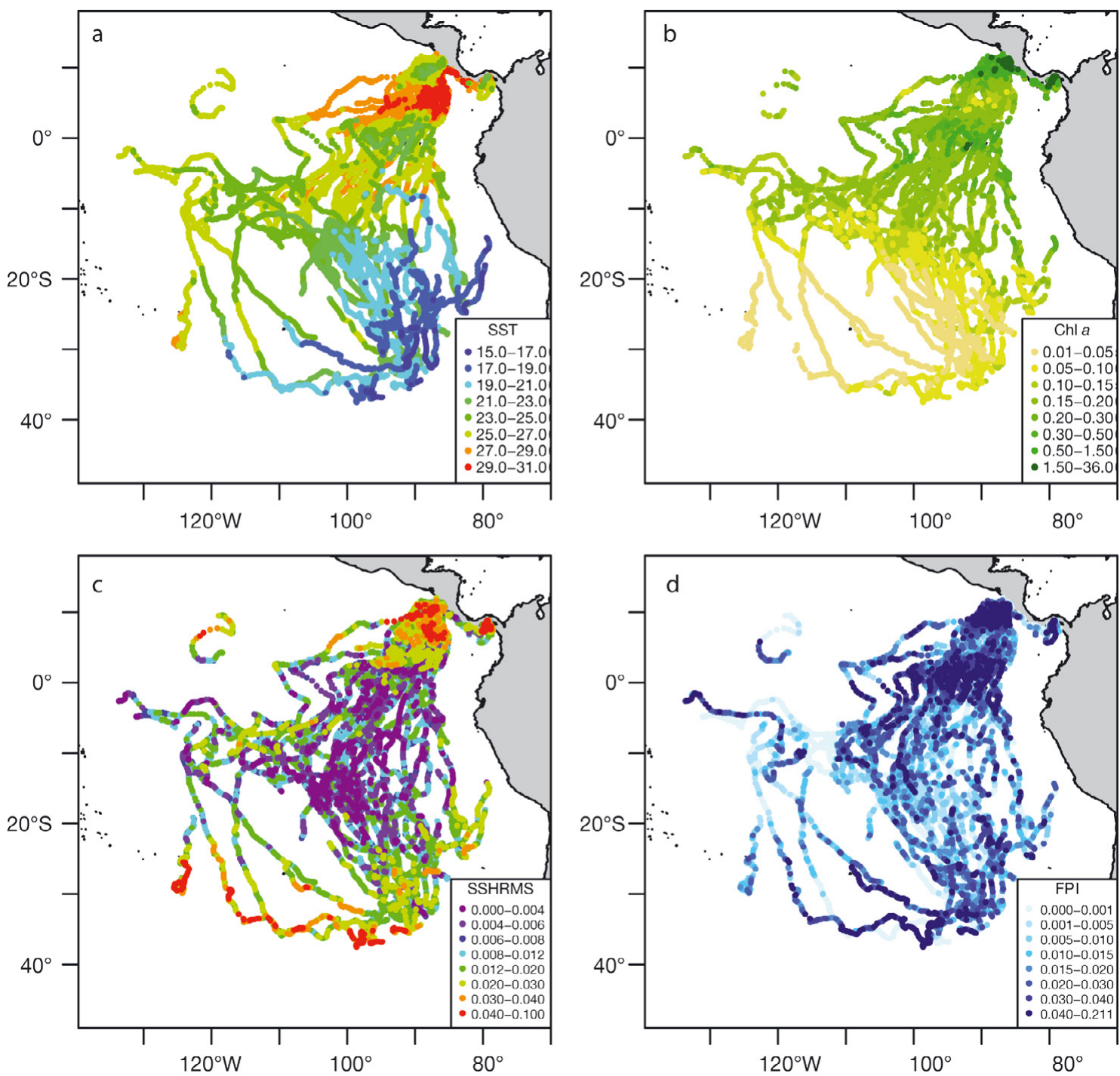

Fig. 4. Dermochelys coriacea. (a) Sea surface temperature $\left(\mathrm{SST}^{\circ}{ }^{\circ} \mathrm{C}\right)$, (b) chl a concentration $\left(\mathrm{mg} \mathrm{m}^{-3}\right)$, (c) sea surface height root mean square (SSHRMS, m), and (d) frontal probability index (FPI) values for all switching state-space model-derived daily turtle positions

therefore travel long distances to reach areas that aggregate gelatinous zooplankton prey, including convergence zones and frontal systems (Polovina et al. 2000, Lambardi et al. 2008).

Our data indicated significant diel periodicity with respect to leatherback dive depth and dive duration during both the migration and foraging phases. Dives were significantly deeper, but shorter during the day than at night. This indicated that daytime dives were exploratory, while more intense feeding occurred at night with shallower, longer dives (Houghton et al. 2008). These observations are supported by recent studies, which suggest that feeding occurs predominantly during nocturnal periods when vertically migrating prey are accessible at shallower depths
(Eckert 2006, Myers \& Hays 2006). Leatherbacks may also be resting or swimming at the surface during the day to maximize absorption of solar radiation (James et al. 2005). Dives were also deeper and longer during the foraging phase than during migration. This is in contrast with the Atlantic, where leatherbacks predominantly performed shallower dives on their northern foraging grounds (James et al. 2006). This difference might indicate an interbasin difference in how leatherback prey is distributed vertically in the water column in foraging areas.

The longest dive duration in the present study (83.8 $\mathrm{min}$ ) neared the longest leatherback dive duration ever reported (López-Mendilaharsu et al. 2009) of 

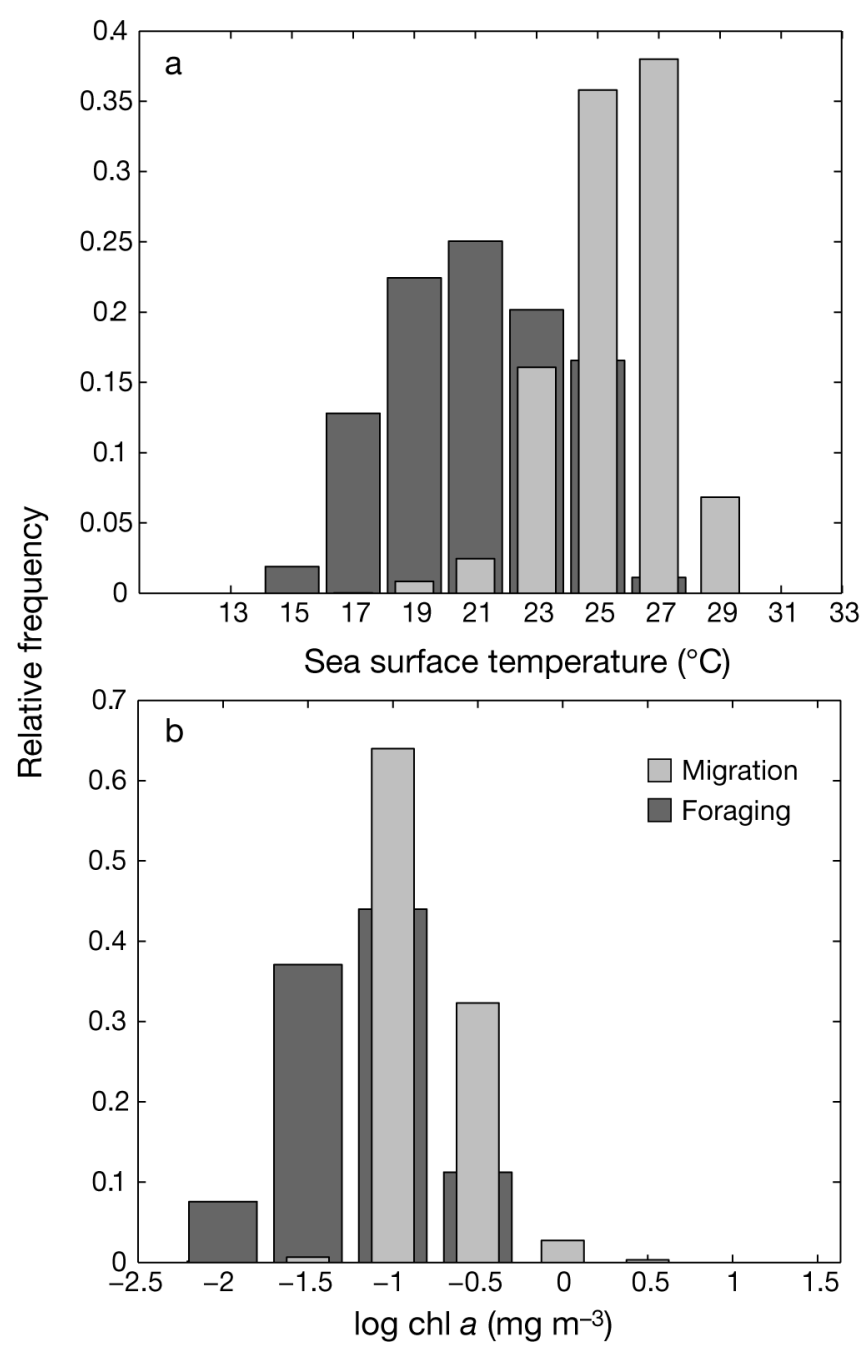

Fig. 5. Dermochelys coriacea. Histograms depicting the relative frequency of satellite-derived (a) sea surface temperature (SST) and (b) surface chlorophyll a (chl a) concentration values associated with turtle positions during the migration (light gray) and foraging (mid-gray) phases

Table 2. Dermochelys coriacea. Results of generalized additive mixed model (GAMM) for daily turtle travel rates (Gaussian error, identity link function) in relation to sea surface temperature (SST), logarithm of surface chlorophyll a $(\mathrm{chl} a)$ concentration, logarithm of root mean square of sea surface height (SSHRMS), arcsine of frontal probability index (FPI), and Ekman upwelling (Ekman). Overall deviance explained was $27 \%$. edf: estimated degrees of freedom

\begin{tabular}{|lccc|}
\hline Smoother term & edf & $F$ & $p$ \\
\hline SST & 6.64 & 75.35 & $<0.001$ \\
Chl $a$ & 7.17 & 41.66 & $<0.001$ \\
SSHRMS & 5.79 & 31.76 & $<0.001$ \\
FPI & 3.00 & 51.68 & $<0.001$ \\
Ekman & 5.73 & 20.06 & $<0.001$ \\
\hline
\end{tabular}

$86.5 \mathrm{~min}$ (to $1186 \mathrm{~m}$ depth) off the Atlantic Coast of South America $\left(29.2^{\circ} \mathrm{S}, 40.7^{\circ} \mathrm{W}\right)$. Dives exceeding $1 \mathrm{~h}$ in duration and $300 \mathrm{~m}$ in depth are rare for leatherback turtles (Houghton et al. 2008). The deepest dives in our data set occurred predominantly during the day and during the initial stages of the migration phase. These early-migration deep dives may be related to orientation or prey searching. In their recent analysis regarding extraordinarily rare and deep leatherback dives, Houghton et al. (2008) ruled out thermoregulation and predator avoidance as possible explanatory factors for this behavior, and identified prey detection and acquisition as the primary driver. They suggested that leatherbacks might be using their heightened visual adaptations to scan the water column for prey while making daytime descents in search of the deep scattering layer. Although there is controversy over the acuity of leatherback vision (Brudenall et al. 2008), chemoreception may also play a role in funding food (Myers \& Hays 2006).

Although we cannot rule out the possibility that turtles were foraging during the migration phase, we suggest that dive behavior during this period might be related to thermoregulation (shedding heat). Leatherbacks retain metabolic heat through a suite of physiological mechanisms, termed 'gigantothermy' (Paladino et al. 1990), in combination with behavioral adjustments to generate heat internally (for review of leatherback thermoregulation, see Wallace \& Jones 2008). These adaptations enable leatherbacks to forage within cold waters at high latitudes and at extreme depths that are inaccessible to other marine turtle species. Leatherbacks are probably challenged to shed heat during their rapid migration through warm equatorial habitats and, like other reptiles, utilize behavioral adjustments to regulate their body temperature (Wallace et al. 2005, Bostrom \& Jones 2007). Conversely, the southern terminus of the turtle tracking range $\left(\sim 37^{\circ} \mathrm{S} ; \mathrm{SST}: \sim 14^{\circ} \mathrm{C}\right)$ might represent the lower thermal limit for leatherback turtles in the eastern Pacific. McMahon \& Hays (2006) found a similar northern limit (SST: $15^{\circ} \mathrm{C}$ ) in the Atlantic, although leatherbacks have been frequently observed within waters with $\mathrm{SST}<15^{\circ} \mathrm{C}$ for brief periods (Jonsen et al. 2007, Eckert et al. 2009). An analysis of turtle size (caudal carapace length, CCL) in relation to southernmost latitude (for tracks of at least $1 \mathrm{yr}$ in duration) indicated that Bergmann's rule was not apparent in this population (linear regression: $\mathrm{R}^{2}=0.15, F_{1,14}=2.59, \mathrm{p}=0.13$ ). This is in contrast to findings in the NE Atlantic, where there was a latitudinal gradient in leatherback turtle body size (Witt et al. 2007).

The persistent migrations of eastern Pacific leatherbacks to the South Pacific Gyre and their subsequent sustained residency within this region suggests that 

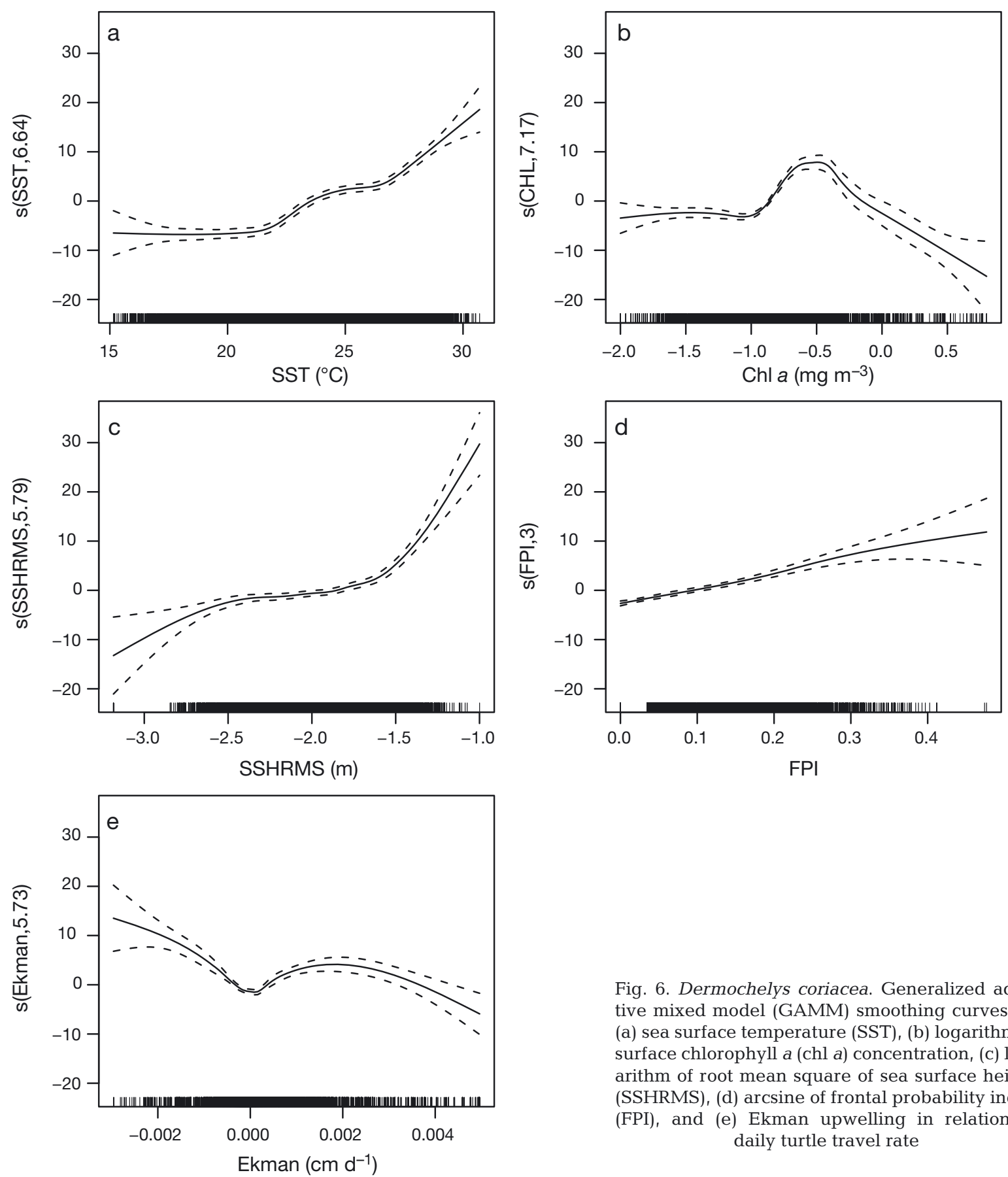

Fig. 6. Dermochelys coriacea. Generalized additive mixed model (GAMM) smoothing curves for (a) sea surface temperature (SST), (b) logarithm of surface chlorophyll a (chl a) concentration, (c) logarithm of root mean square of sea surface height (SSHRMS), (d) arcsine of frontal probability index (FPI), and (e) Ekman upwelling in relation to daily turtle travel rate

this population may exhibit foraging site fidelity, as has been documented for other leatherback populations (James et al. 2005), However, this area appears to be much larger and more diffuse than those foraging areas where turtles exhibit fidelity in the Atlantic (James et al. 2005). Studies documenting repeated remigrations by individual turtles in the eastern Pacific are necessary to substantiate this hypothesis. We did not observe in the eastern Pacific population the varia-

tion of migration patterns that have been recorded in the North Atlantic (Hays et al. 2006) or western Pacific (Benson et al. 2007), or for other marine turtle species (McClellan \& Read 2007, Mansfield et al. 2009). This, together with their specialist diet, suggests that eastern Pacific leatherbacks may be particularly vulnerable to environmental variation and climate change that affects prey availability (Hawkes et al. 2009, Wallace \& Saba 2009). 


\section{Applications for conservation}

Marine spatial planning, especially in high-seas areas where many activities by multiple nations occur, requires robust information about interactions between marine biodiversity and environmental variables to design coherent, integrated approaches for conservation (Crowder \& Norse 2008). In addition, connections between marine populations and oceanographic processes warrant ecosystem-based conservation approaches to ensure ecosystem viability (Foley et al. 2010). Our analyses underscored the importance of the South Pacific Gyre and adjacent pelagic realms as key feeding areas for adult eastern Pacific leatherbacks, a genetically unique population (Dutton et al. 1999) that has all but collapsed (Spotila et al. 2000) and whose distribution spans the eastern Pacific Ocean (Shillinger et al. 2008, present study). Because this region is also important for other marine turtle species, marine mammals, and seabirds, as well as commercially important species such as tuna and billfish, sardines, and anchoveta, a multi-scaled, interinstitutional management scheme focused on ensuring healthy ecosystem function would be ideal.

Our characterization of 3-dimensional habitat use by leatherbacks in the South Pacific Gyre relative to oceanographic features provides managers with valuable, detailed information to identify potential spatiotemporal overlaps between turtle habitat and fishing gear operations. A present-day example of this type of application exists in the TurtleWatch program, which provides recommendations to Hawaii-based longline fishers on areas to fish to avoid interactions with loggerhead turtles Caretta caretta based on known relationships between turtles and SST derived from satellite telemetry studies (Polovina et al. 2004, Howell et al. 2008). To adopt a congruent approach in the southeastern Pacific, we recommend integrating our analyses of leatherback movements and behaviors in an oceanographic context with characterizations of fisheries activities in response to environmental conditions in the region. To do this, implementation of vessel monitoring systems in the region would provide valuable information about fishing operations in time and space (Witt \& Godley 2007, Shillinger et al. 2008), which could be integrated with leatherback movement data to inform ecosystem-based marine spatial planning efforts in the region. Our results can also inform strategic employment of bycatch reduction measures (e.g. gear modifications for longlines, timearea closures) and on-board observer programs currently in place in the region (IATTC 2004, FAO 2010). Furthermore, the tag-derived environmental data can be utilized to calibrate oceanographic remotely sensed data, which is also very important oceano- graphically and for management of high-seas ecosystems.

Overall fishing effort and sea-turtle bycatch rates in multiple gears in the East Pacific Ocean rank among the highest in the world, and fisheries in the southeastern Pacific vary tremendously in type (e.g. longlines, gillnets, purse seines, trawls) and scale (coastal, artisanal to pelagic, industrial) (Wallace et al. 2010). Although refined spatial data are scarce, leatherbacks have been documented to interact with pelagic longlines (Donoso \& Dutton 2010) and driftnets (Frazier \& Montero 1990, Eckert \& Sarti 1997), as well as smallscale gillnets (Alfaro-Shigueto et al. 2007). Ideally, designation of a pelagic multi-use protected area within the South Pacific Gyre could reduce (or eliminate) mortality of leatherback turtles from fisheries interactions, and could also benefit other marine species. Toward this approach, we encourage integrated efforts by multinational conservation frameworks and policy instruments - e.g. the Inter-American Tropical Tuna Commission, the Inter-American Convention for the Conservation and Protection of Sea Turtles, Convention on Highly Migratory Species, Comisión Permanente del Pacífico Sur, United Nations Convention on the Law of the Sea, South Pacific Regional Fisheries Management Organization and Eastern Tropical Pacific Seascape (Shillinger 2005) - to manage effectively this important high-seas ecosystem. All parties that participate in the extraction of shared resources in international waters also share responsibility for the management of those resources and for the persistence of marine biodiversity in these regions.

Acknowledgements. This research was sponsored by the Tagging of Pacific Predators program of the Census of Marine Life, and supported by the Office of Naval Research, the UNESCO World Heritage Program (via the United Nations Foundation and Global Conservation Fund of Conservation International), the Alfred P. Sloan Foundation, the Gordon and Betty Moore Foundation, the Packard Foundation, the Lenfest Ocean Program, the Cinco Hermanos Fund, Earthwatch Institute, and the National Aeronautics and Space Administration (NASA) through a grant provided by the Applied Sciences Program in the Earth Science Division. The research was performed in accordance with the Stanford University Animal Care and Use Committee. The authors thank The Leatherback Trust, Earthwatch Institute, and the Betz Chair of Environmental Science at Drexel University for their assistance with this project. The altimeter products were produced by Ssalto/Duacs and distributed by Aviso, with support from the Centre National d'Etudes Spatiales, France. The authors thank the Ocean Biology Processing Group at the NASA/Goddard Space Flight Center for the production and distribution of the SeaWiFS ocean color data. These activities are sponsored by NASA's Mission to Planet Earth Program. The Smith and Sandwell digital bathymetry was obtained from the Institute of Geophysics and Planetary Physics at the Scripps Institution of Oceanography. We thank 
J. Thompson, J. Wible, S. Eckert, D. Foley, D. Palacios, L. DeWitt, M. Fedak, P. Lovell, J. Ganong, D. Kohrs, V. Saba, and P. Santidrián-Tomillo for technical assistance. The Costa Rican Ministry of Natural Resources and the Environment provided research permits. We also thank G. Goldring, the Goldring Marine Biology Station, and the staff and volunteers at Parque Nacional Marino Las Baulas for support at Playa Grande. This is contribution number 4483 of the University of Maryland Center for Environmental Science (UMCES).

\section{LITERATURE CITED}

Alfaro-Shigueto J, Dutton PH, Van Bressem MF, Mangel J (2007) Interactions between leatherback turtles and Peruvian artisanal fisheries. Chelonian Conserv Biol 6:129-134

Ardron J, Gjerde K, Pullen S, Tilot V (2008) Marine spatial planning in the high seas. Mar Policy 32:832-839

Bailey H, Thompson PM (2009) Using marine mammal habitat modelling to identify priority conservation zones within a marine protected area. Mar Ecol Prog Ser 378:279-287

Bailey H, Shillinger G, Palacios D, Bograd S, Spotila J, Paladino $F$, Block B (2008) Identifying and comparing phases of movement by leatherback turtles using state-space models. J Exp Mar Biol Ecol 356:128-135

> Benson SR, Dutton PH, Hitipeuw C, Samber B, Bakarbessy J, Parker D (2007) Post-nesting migrations of leatherback turtles (Dermochelys coriacea) from Jamursba-Medi, Bird's Head Peninsula, Indonesia. Chelonian Conserv Biol 6:150-154

Block BA, Costa DP, Boehlert GW, Kochevar RE (2002) Revealing pelagic habitat use: the tagging of Pacific pelagics program. Oceanol Acta 25:255-266

Bostrom BL, Jones DR (2007) Exercise warms adult leatherback turtles. Comp Biochem Physiol A 147:323-331

Brudenall DK, Schwab IR, Fritsches KA (2008) Ocular morphology of the leatherback sea turtle (Dermochelys coriacea). Vet Ophthalmol 11:99-110

Byrne R, Fish J, Doyle TK, Houghton JDR (2009) Tracking leatherback turtles (Dermochelys coriacea) during consecutive inter-nesting intervals: further support for direct transmitter attachment. J Exp Mar Biol Ecol 377:68-75

Cañadas A, Sagarminaga R, de Stephanis R, Urquiola E, Hammond PS (2005) Habitat preference modelling as a conservation tool: proposals for marine protected areas for cetaceans in southern Spanish waters. Aquat Conserv Mar Freshw Ecosyst 15:495-521

Crowder L, Norse E (2008) Essential ecological insights for marine ecosystem-based management and marine planning. Mar Policy 32:772-778

Donoso M, Dutton PH (2010) Sea turtle bycatch in the Chilean pelagic longline fishery in the southeastern Pacific: opportunities for conservation. Biol Conserv 143:2672-2684

Douvere F, Maes F, Vanhulle A, Schrijvers J (2007) The role of marine spatial planning in sea use management: the Belgian case. Mar Policy 31:182-191

> Doyle TK, Houghton JDR, O'Súilleabháin PF, Hobson VJ, Marnell F, Davenport J, Hays GC (2008) Leatherback turtles satellite-tagged in European waters. Endang Species Res 4:23-31

Ducet NP, Le Traon PY, Reverdin G (2000) Global high-resolution mapping of ocean circulation from TPOX/Poseidon and ERS-1 and -2. J Geophys Res 105:19477-19498

> Dutton PH, Bowen BW, Owens DW, Barragan A, Davis SK (1999) Global phylogeography of the leatherback turtle
(Dermochelys coriacea). J Zool 248:397-409

Eckert SA (2002) Swim speed and movement patterns of gravid leatherback sea turtles (Dermochelys coriacea) at St Croix, US Virgin Islands. J Exp Biol 205:3689-3697

- Eckert SA (2006) High-use oceanic areas for Atlantic leatherback sea turtles (Dermochelys coriacea) as identified using satellite telemetered location and dive information. Mar Biol 149:1257-1267

Eckert SA, Sarti L (1997) Distant fisheries implicated in the loss of the world's largest leatherback nesting population. Mar Turtle Newsl 78:2-7

Eckert KL, Wallace BP, Frazier JG, Eckert SA, Pritchard PCH (2009) Synopsis of the biological data on the leatherback sea turtle, Dermochelys coriacea (Vandelli, 1761). US Fish and Wildlife Service, Jacksonville, FL

FAO (Food and Agriculture Organization of the United Nations) (2010) Guidelines to reduce sea turtle mortality in fishing operations. FAO, Rome

> Fauchald P, Tveraa T (2003) Using first-passage time in the analysis of area-restricted search and habitat selection. Ecology 84:282-288

> Fedak M, Lovell P, McConnell B, Hunter C (2002) Overcoming the constraints of long range radio telemetry from animals: getting more useful data from smaller packages. Integr Comp Biol 42:3-10

> Foley MM, Halpern BS, Micheli F, Armsby MH and others (2010) Guiding ecological principles for marine spatial planning. Mar Policy 34:955-966

> Fossette S, Corbel H, Gaspar P, Le Maho Y, Georges JY (2008) An alternative technique for the long-term satellite tracking of leatherback turtles. Endang Species Res 4:33-41

Frazier JG, Montero JLB (1990) Incidental capture of marine turtles by the swordfish fishery at San Antonio, Chile. Mar Turtle Newsl 49:8-13

Game ET, Grantham HS, Hobday AJ, Pressey RL and others (2009) Pelagic protected areas: the missing dimension in ocean conservation. Trends Ecol Evol 24:360-369

Halpern BS, Walbridge S, Selkoe KA, Kappel CV and others (2008) A global map of human impact on marine ecosystems. Science 319:948-952

> Hart KM, Hyrenbach KD (2009) Satellite telemetry of marine megavertebrates: the coming of age of an experimental science. Endang Species Res 10:9-20

Hawkes LA, Broderick AC, Godfrey MH, Godley BJ (2009) Climate change and marine turtles. Endang Species Res $7: 137-154$

Hays GC, Houghton JDR, Myers AE (2004) Pan-Atlantic leatherback turtle movements. Nature 429:522

Hays GC, Hobson VJ, Metcalfe JD, Righton D, Sims DW (2006) Flexible foraging movements of leatherback turtles across the North Atlantic Ocean. Ecology 87:2647-2656

Houghton JDR, Doyle TK, Davenport J, Wilson RP, Hays GC (2008) The role of infrequent and extraordinary deep dives in leatherback turtles (Dermochelys coriacea). J Exp Biol 211:2566-2575

Howell EA, Kobayashi DR, Parker DM, Balazs GH, Polovina JJ (2008) TurtleWatch: a tool to aid in the bycatch reduction of loggerhead turtles Caretta caretta in the Hawaiibased pelagic longline fishery. Endang Species Res 5: $267-278$

> Hyrenbach KD, Forney KA, Dayton PK (2000) Marine protected areas and ocean basin management. Aquat Conserv Mar Freshw Ecosyst 10:437-458

IATTC (Inter-American Tropical Tuna Commission) (2004) Interactions of sea turtles with tuna fisheries, and other impacts on turtle populations. Working Group on Bycatch, 
4th meeting, Kobe, Japan. IATTC, La Jolla, CA

James MC, Myers RA, Ottensmeyer CA (2005) Behaviour of leatherback sea turtles, Dermochelys coriacea, during the migratory cycle. Proc R Soc B Biol Sci 272:1547-1555

James MC, Ottensmeyer CA, Eckert SA, Myers RA (2006) Changes in diel diving patterns accompany shifts between northern foraging and southern migration in leatherback turtles. Can J Zool 84:754-765

> Jonsen ID, Myers RA, James MC (2007) Identifying leatherback turtle foraging behaviour from satellite-telemetry using a switching state-space model. Mar Ecol Prog Ser 337:255-264

Kuhn CE, Crocker DE, Tremblay Y, Costa DP (2009) Time to eat: measurements of feeding behaviour in a large marine predator, the northern elephant seal Mirounga angustirostris. J Anim Ecol 78:513-523

Lambardi P, Lutjeharms JRE, Mencacci R, Hays GC, Luschi P (2008) Influence of ocean currents on long-distance movement of leatherback sea turtles in the Southwest Indian Ocean. Mar Ecol Prog Ser 353:289-301

> Lewison RL, Freeman SA, Crowder LB (2004) Quantifying the effects of fisheries on threatened species: the impact of pelagic longlines on loggerhead and leatherback sea turtles. Ecol Lett 7:221-231

López-Mendilaharsu M, Rocha CFD, Miller P, Domingo A, Prosdocimi L (2009) Insights on leatherback turtle movements and high use areas in the Southwest Atlantic Ocean. J Exp Mar Biol Ecol 378:31-39

> Mansfield KL, Saba VS, Keinath JA, Musick JA (2009) Satellite tracking reveals a dichotomy in migration strategies among juvenile loggerhead turtles in the Northwest Atlantic. Mar Biol 156:2555-2570

McClellan CM, Read AJ (2007) Complexity and variation in loggerhead sea turtle life history. Biol Lett 3:592-594

McClellan CM, Read AJ, Price BA, Cluse WM, Godfrey MH (2009) Using telemetry to mitigate the bycatch of longlived marine vertebrates. Ecol Appl 19:1660-1671

McMahon CR, Hays GC (2006) Thermal niche, large-scale movements and implications of climate change for a critically endangered marine vertebrate. Glob Change Biol 12:1330-1338

Morreale SJ, Standora EA, Spotila JR, Paladino FV (1996) Migration corridor for sea turtles. Nature 384:319-320

- Myers AE, Hays GC (2006) Do leatherback turtles Dermochelys coriacea forage during the breeding season? A combination of data-logging devices provide new insights. Mar Ecol Prog Ser 322:259-267

Olson RJ, Galván-Magaña F (2002) Food habits and consumption rates of common dolphinfish (Coryphaena hippurus) in the eastern Pacific Ocean. Fish Bull 100:279-298

> Paladino FV, O'Connor MP, Spotila JR (1990) Metabolism of leatherback turtles, gigantothermy, and thermoregulation of dinosaurs. Nature 344:858-860

Plotkin PT, Byles RA, Rostal DC, Owens DW (1995) Independent versus socially facilitated oceanic migrations of the olive ridley, Lepidochelys olivacea. Mar Biol 122: $137-143$

> Polovina JJ, Kobayashi DR, Parker DM, Seki MP, Balazs GH (2000) Turtles on the edge: movement of loggerhead turtles (Caretta caretta) along oceanic fronts, spanning longline fishing grounds in the central North Pacific, $1997-$ 1998. Fish Oceanogr 9:71-82

> Polovina JJ, Balazs GH, Howell EA, Parker DM, Seki MP, Dutton PH (2004) Forage and migration habitat of loggerhead (Caretta caretta) and olive ridley (Lepidochelys olivacea) sea turtles in the central North Pacific Ocean. Fish
Oceanogr 13:36-51

R Development Core Team (2008) R: a language and environment for statistical computing. R Foundation for Statistical Computing, Vienna. www.R-project.org

> Rasmussen K, Palacios DM, Calambokidis J, Saborío MT and others (2007) Southern Hemisphere humpback whales wintering off Central America: insights from water temperature into the longest mammalian migration. Biol Lett 3:302-305

Redfern JV, Barlow J, Ballance LT, Gerrodette T, Becker EA (2008) Absence of scale dependence in dolphin-habitat models for the eastern tropical Pacific Ocean. Mar Ecol Prog Ser 363:1-14

Reina RD, Abernathy KJ, Marshall GJ, Spotila JR (2005) Respiratory frequency, dive behaviour and social interactions of leatherback turtles, Dermochelys coriacea during the inter-nesting interval. J Exp Mar Biol Ecol 316:1-16

Saba VS, Shillinger GL, Swithenbank AM, Block BA, Spotila JR, Musick JA, Paladino FV (2008) An oceanographic context for the foraging ecology of eastern Pacific leatherback turtles: consequences of ENSO. Deep-Sea Res I 55: $646-660$

Santidrián Tomillo P, Vélez E, Reina RD, Piedra R, Paladino FV, Spotila JR (2007) Reassessment of the leatherback turtle (Dermochelys coriacea) nesting population at Parque Nacional Marino Las Baulas, Costa Rica: effects of conservation efforts. Chelonian Conserv Biol 6:54-62

> Santidrián Tomillo P, Saba VS, Piedra R, Paladino FV, Spotila JR (2008) Effects of illegal harvest of eggs on the population decline of leatherback turtles in Las Baulas Marine National Park, Costa Rica. Conserv Biol 22:1216-1224

> Sarti Martínez L, Barragán AR, Muñoz DG, García N, Huerta $\mathrm{P}$, Vargas F (2007) Conservation and biology of the leatherback turtle in the Mexican Pacific. Chelonian Conserv Biol 6:70-78

Seminoff JA, Zárate P, Coyne MS, Foley DG, Parker D, Lyon BN, Dutton PH (2008) Post-nesting migrations of Galápagos green turtles Chelonia mydas in relation to oceanographic conditions: integrating satellite telemetry with remotely sensed ocean data. Endang Species Res $4: 57-72$

Shillinger GL (2005) The Eastern Tropical Pacific Seascape: an innovative model for transboundary marine conservation. In: Mittermeier RA, Kormos CF, Mittermeier PRG, Sandwith T, Besancon C (eds) Transboundary conservation: a new vision for protected areas. Conservation International, Washington, DC, p 320-331

Shillinger GL, Palacios DM, Bailey H, Bograd SJ and others (2008) Persistent leatherback turtle migrations present opportunities for conservation. PLoS Biol 6:e171

Shillinger GL, Swithenbank AM, Bograd SJ, Bailey H and others (2010) Identification of high-use internesting habitats for eastern Pacific leatherback turtles: role of the environment and implications for conservation. Endang Species Res 10:215-232

Southwood AL, Andrews RD, Paladino FV, Jones DR (2005) Effects of diving and swimming behavior on body temperatures of Pacific leatherback turtles in tropical seas. Physiol Biochem Zool 78:285-297

Spotila JR, Reina RD, Steyermark AC, Plotkin PT, Paladino FV (2000) Pacific leatherback turtles face extinction. Nature 405:529-530

Wallace BP, Jones TT (2008) What makes marine turtles go: a review of metabolic rates and their consequences. J Exp Mar Biol Ecol 356:8-24

Wallace BP, Saba VS (2009) Environmental and anthro- 
pogenic impacts on intra-specific variation in leatherback turtles: opportunities for targeted research and conservation. Endang Species Res 7:11-21

Wallace BP, Williams CL, Paladino FV, Morreale SJ, Lindstrom RT, Spotila JR (2005) Bioenergetics and diving activity of internesting leatherback turtles Dermochelys coriacea at Parque Nacional Marino Las Baulas, Costa Rica. J Exp Biol 208:3873-3884

- Wallace BP, Lewison RL, McDonald SL, McDonald RK and others (2010) Global patterns of marine turtle bycatch. Conserv Lett 3:131-142

> Whitehead H, Coakes A, Jaquet N, Lusseau S (2008) Movements of sperm whales in the tropical Pacific. Mar Ecol

Editorial responsibility: Hans Heinrich Janssen, Oldendorf/Luhe, Germany
Prog Ser 361:291-300

Witt MJ, Godley BJ (2007) A step towards seascape scale conservation: using vessel monitoring systems (VMS) to map fishing activity. PLoS ONE 2:e1111

Witt MJ, Broderick AC, Johns DJ, Martin C, Penrose R, Hoogmoed MS, Godley BJ (2007) Prey landscapes help identify potential foraging habitats for leatherback turtles in the NE Atlantic. Mar Ecol Prog Ser 337:231-244

Wood SN (2006) Generalized additive models: an introduction with R. Chapman \& Hall/CRC, Boca Raton, FL

Zuur AF, Ieno EN, Walker NJ, Saveliev AA, Smith GM (2009) Mixed effects models and extensions in ecology with R. Springer, New York, NY

Submitted: July 22, 2010; Accepted: October 19, 2010

Proofs received from author(s): January 13, 2011 